\title{
Paradoxos na construção do SUS
}

| ${ }^{1}$ Gastão Wagner de Sousa Campos |

1 Professor titular de Saúde Coletiva, Faculdade de Ciências Médicas, UNICAMP. Endereço eletrônico: gastaowagner@mpc.com.br

Utilizarei o conceito de "paradoxo", neste ensaio, para indicar situaçôes em que fatores econômicos e políticos, atuando de forma concomitante, tenderão a produzir efeitos diferentes e, algumas vezes, até mesmo antagônicos.

Em minha compreensão, o principal paradoxo do Sistema Único de Saúde (SUS) se origina no fato de ele se pretender uma política pública em um período histórico de grande desprestígio das políticas públicas. Em realidade, o sentido essencial do SUS, e principal razão de sua existência, é sua suposta capacidade de assegurar o direito universal à saúde. No Brasil, em grande medida, vem se desenvolvendo uma política nacional com esse objetivo; a expressão mais concreta disto são os próprios serviços já oferecidos pelo SUS. Ao mesmo tempo, contudo, existem forças sociais interessadas em alocar e utilizar os recursos financeiros, e ainda aqueles de outra ordem, segundo o interesse de agentes privados, que atuam dentro da perspectiva do mercado.

A hipótese deste ensaio é que a superação desse conflito dependerá tanto da funcionalidade do SUS, capacidade de atender a necessidades sociais de forma equitativa e integral, quanto da produção de um projeto comum de sociedade que combine interesses privados com aqueles públicos.

O SUS tem um caráter duplo: é, ao mesmo tempo, uma instituição pública (constituído a partir de um sistema legal e com uma estrutura concreta) e uma política (práxis). Esta duplicidade lhe dá uma dinâmica paradoxal em que se chocam forças estabilizadoras, com outras, oriundas da sociedade civil, que produzem movimento e instabilidade. Essa dinâmica vem resultando tanto no crescimento e consolidação dessa política, quanto no esforço para desconstruir e 
limitar o escopo do SUS. A defesa do SUS tem sido reforçada pelo estabelecido na Constituição, pelo efeito da demonstração de programas exitosos e pela luta do movimento de reforma sanitária. A contrarreforma sanitária tem sido bancada pelo pensamento e prática conservadora, liberal e clientelista.

Há um embate cultural, ideológico e político entre um discurso que é enfático em atribuir ao empreendedorismo individual o principal fator para assegurar desenvolvimento, estabilidade e bem-estar social, e outro que ainda considera as políticas públicas como essenciais para lograr essas mesmas finalidades. Políticas públicas são açôes sociais baseadas no empreendedorismo coletivo e do Estado (utilizo o conceito de sujeito empreendedor, tão em moda, para ressaltar o paradoxo em análise). As políticas públicas, o SUS entre elas, pressupõem leis, políticas, gestão de sistemas, de organizações e do trabalho que limitem os efeitos antissociais da livre-iniciativa e que ainda produzam solidariedade e proteção aos vulneráveis. A Saúde Pública moderna, desde sua origem, tem enfrentado esta disjunção de interesses e de perspectivas (SIGERIST, 2011). A cidade saudável, a saúde dos trabalhadores e dos consumidores, a defesa do planeta e o direito universal à saúde somente se realizam quando se consegue construir instituições, e um estilo de trabalho, com importante grau de autonomia do poder econômico.

Não há como defender o SUS sem o fortalecimento de uma perspectiva ético-política referente à necessária construção de relaçōes mais equilibradas entre os interesses corporativos e as necessidades coletivas. A democracia e o bem-estar social somente serão alcançados mediante a criação de condições favoráveis ao protagonismo das pessoas, mas também mediante a instituição de orçamento público com base em sistemas progressivos de arrecadação de impostos, para a consolidação de políticas e de gestão pública em vários campos para além da saúde: cidades, transporte, habitação, educação, clima, ambiente, segurança, entre outros.

A estabilidade do SUS depende, portanto, da constituição de uma sociedade que busque sempre lidar, de modo democrático, com a contradição entre direitos e interesses individuais e a constituição de modos de governar voltados para o coletivo.

A experiência de substituir totalmente o mercado pelo Estado burocrático fracassou no século $\mathrm{XX}$. $\mathrm{O}$ socialismo realmente existente não logrou legitimidade social. No entanto, as sociedades que combinaram políticas 
públicas com mercado alcançaram grande legitimidade social. Por meio de proteção legislativa ao trabalhador, aos idosos, ao ambiente, aos consumidores, aos vulneráveis, bem como implementação de sistemas públicos com modelos de gestão e de cuidado centrados na necessidade das pessoas e não na rentabilidade econômica, demonstrou-se que se pode organizar sociedades heterogêneas com forte consciência e solidariedade social. O combate a estas políticas sociais nos últimos anos reflete mais a dinâmica política e econômica do interesse do capital do que o fracasso destas iniciativas (PIKETTI, 2014).

Acredito que se pode sintetizar esse paradoxo com a seguinte formulação: o SUS é o reconhecimento legal e prático de que o mercado, por si só, não garantirá o direito universal à saúde. Entretanto, ao mesmo tempo, ao longo de todo o processo de implementação do SUS, no concreto, tem-se elaborado normas, adotado modelos de gestão e de financiamento contrários à racionalidade das políticas e dos sistemas públicos de saúde (PAIM; 2008).

A segunda dimensão desse mesmo paradoxo é, portanto, a repetição compulsiva de discursos e estratégias de contrarreforma sanitária que objetivam trazer para dentro do SUS a lógica e a racionalidade do mercado. Para enfrentar esta ofensiva conservadora, urge reforçar o contraditório por meio da defesa do prosseguimento de novas alternativas para a gestão pública e para a organização do trabalho em saúde. É fundamental recusarmos todas as tentativas de desconstrução do SUS por meio da introdução de pedaços de mercado dentro de sua dinâmica - refiro-me à crescente privatização e terceirização em que a eficiência e a rentabilidade econômica dos novos "agentes e colaboradores" se sobrepõem à efetividade sanitária dos novos investimentos.

Há que se enfrentar esta disjunção sem subterfúgios. Levantar o véu construído para ocultar este proceder contraditório. Apontar e criticar análises e propostas que, em nome da modernidade, do realismo e do pragmatismo, tratam de, na prática, desconstruir os efeitos sociais do SUS. Ainda quando sempre o façam em nome da salvação do próprio SUS.

O SUS depende do fortalecimento da consciência e da responsabilidade social entre os brasileiros. $\mathrm{O}$ culto ao empreendedorismo individual sugere que não precisaremos mais de políticas públicas. Mais grave: advoga que elas não somente induzem à acomodação, pelo caráter paternalista, mas, principalmente, consomem recursos que seriam empregados, com melhores resultados, no mercado. No Brasil, 
a discussão se complica tendo em vista o caráter patrimonialista com que veio se constituindo o Estado brasileiro, criando um padrão de relação público-privado degradado. Ainda quando o SUS tenha sido arquitetado com outro propósito, e que vários recursos organizacionais tenham sido implementados para assegurar o caráter público ao sistema, não se logrou superar tal contradição.

Um terceiro plano deste paradoxo se refere à crise de representação social contemporânea. Grande parte dos partidos, sindicatos e intelectuais, antes defensores do avanço democrático e de políticas públicas, abandonaram este ideário, trocando-o pela busca obsessiva do poder de Estado (BETTO, 2006). No entanto, existe base social na sociedade brasileira que ainda aposta na democratização e na justiça social. A superação desse descompasso dependerá da capacidade de organização e representação desta parcela, a partir de novas formas de atuação política, tendo em vista o descrédito da maneira tradicional de se fazer política.

O SUS depende do que fizermos com ele, mas também do que acontecerá na sociedade brasileira: na política, na forma de governo, nas relaçôes sociais e econômicas.

\section{Referências}

BETTO, F. A mosca azul: reflexão sobre o poder. Rio de Janeiro: Rocco; 2006.

PAIM, J. S. Reforma Sanitária Brasileira: contribuição para compreensão e crítica. Salvador, EdUFBa; Rio de Janeiro: Fiocruz; 2008.

PIKETTY, T. O Capital no século XXI. Rio de Janeiro: Intrínseca, 2014.

SIGERIST, H. E. Civilização \& Doença. São Paulo: Hucitec, 2011. 